\title{
THE INSCRIPTION FROM APHRODISIAS AND THE PROBLEM OF GOD-FEARERS ${ }^{1}$
}

\author{
Irina A. Levinskaya
}

The problem of God-fearers has once again become a focus of attention following the publication of the Jewish inscription from Aphrodisias. ${ }^{2}$ In fact, the names of $\theta \in 0 \sigma \epsilon \beta \in \hat{\imath} s$ are not only

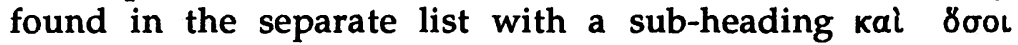

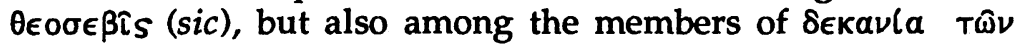

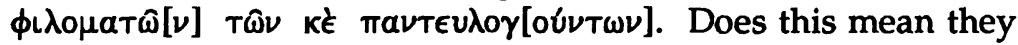
were members of the community? The first and only parallel that comes to mind is the first century $\mathrm{AD}$ Bosporan manumission letter which states: ${ }^{3}$

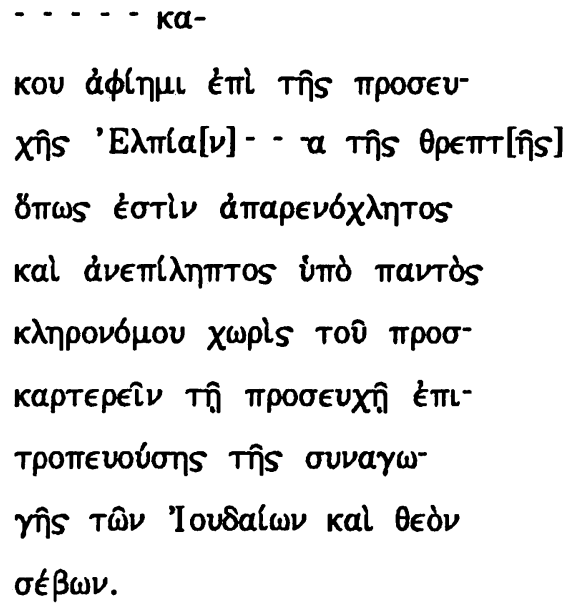

\footnotetext{
${ }^{1}$ I should like to express my sincere debt to Dr E. Bammel, Dr B. Winter, Prof. G. Vermes and Dr. M. Goodman, my thanks to all with whom I had the pleasure of working in Tyndale House's friendly atmosphere, and my gratitude to Sarah Wright who turned this article into better English than I could have produced. 2J. Reynolds and R. Tannenbaum, Jews and God-fearers at Aphrodisias: Greek Inscriptions with Commentary, Proceedings of the Cambridge Philological Association Supp. 12 (Cambridge Philological Society 1987).

${ }^{3} C I R B$ 71. A famous inscription from the theatre at Miletus (CIJ 748), notwithstanding possible interpretation, gives no information about the composition of the Jewish community.
} 
I free in the prayer-house Elpia. . .of the household slavegirl so that he will be protected from disturbance or capture by any of my heirs, on condition that he works for the prayer-house under the guardianship of the Jewish community, and honours God.

H. Bellen in 1965 and B. Lifshitz in 1969 independently made the same emendation to this inscription- $\theta \epsilon 0<\nu>\sigma \in \beta \omega \nu .^{4}$ This means that the freedman was under the guardianship of the community, which consisted both of Jews and God-fearers. The reason for this correction is quite clearly the grammatical awkwardness of the addition kal $\theta \epsilon \delta \nu \quad \sigma \epsilon \beta \omega \nu$. Bellen, who, quite rightly, was not satisfied with the poor quality of the published photograph of this inscription, ${ }^{5}$ asked the Leningrad branch of the Institute of Archaeology, where the photographs of the Bosporan inscriptions are kept, to send him another copy. After receiving the copy he came to the conclusion that the first editor, as well as all those who had discussed this inscription subsequently, ${ }^{6}$ had read it wrongly: 'Der auf das A von E $\Lambda$ III A folgende deformierte Buchstabe scheint zudem kein $\mathrm{N}$, sondern

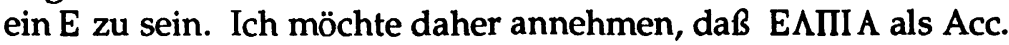
von ' $\mathrm{E} \lambda \pi$ l $s$ verstehen ist, also $\mathrm{zu}{ }^{\prime} \mathrm{E} \lambda \mathrm{Tl}(\delta) \alpha$ emendiert werden muß'. ${ }^{7}$ In other words, instead of a man's name ('E $\lambda \pi i(a s)$, Bellen saw a woman's name ('E $E$ mis). This, of course, makes the reading kai $\theta \epsilon \dot{\partial} \nu \sigma \epsilon \beta \omega \nu$ absolutely impossible and makes emendation essential. However, my acquaintance with photographs of this inscription taken from various angles convinces me that the evidence does not support Bellen's reading. So I will work on the assumption that we cannot take it for granted that a woman's name appears in the inscription.

How necessary is this emendation? Deviations from Greek grammar are characteristic of Bosporan inscriptions. For instance, in the inscription in question, instead of the

\footnotetext{
${ }^{4} \mathrm{H}$. Bellen 'Die Aussage einer bosporanishen Freilassungsinshrift (CIRB 71) zum Problem der "Gottfürchtigen", JAC 8 (1965) 171-176, B. Lifshitz 'Notes d'épigraphie grecque', RB 76 (1969) 95f.

5J.J. Marti. 'Novye epigraficheskie pamyatniki Bospora', Izvestiya gosudarstoennoi akademii istorii material'noi kul'tury 104 (1934), 67, fig. 6.

'See for instance CIRB 71, B. Nadel, Biuletyn zydooskiego Institutu Historycznego 27 (1958) 12 , n. 5.

${ }^{7} \mathrm{H}$. Bellen, op. cit. 174 .
} 
conjunctive required, we find the indicative $8 \pi \omega s \xi \sigma \tau l \nu .{ }^{8}$ Hence the awkward addition of kal $\theta \in \dot{\delta} \nu \quad \sigma \epsilon \beta \omega \nu$ is possible against the background of Bosporan Greek grammar. On the other hand, what did this addition mean, and why was it made? In three other manumissions from the Bosporan kingdom the word

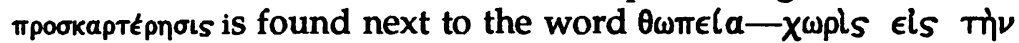

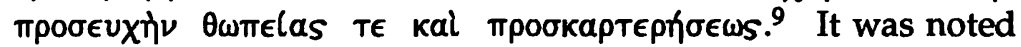
long ago that in the Bosporus the word $\theta \omega \pi \epsilon l \alpha$, which usually means 'flattery', has a special meaning: 'devotion to the prayer-house', i.e. devotion to what takes place in the prayer-

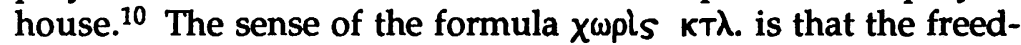
man received freedom on two conditions: firstly, that he should respect the cult, and secondly, that he should work for the prayer-house. ${ }^{11}$ But it would be impossible to fulfil the second condition without fulfilling the first-it is difficult to imagine that people who did not respect the prayer-house would have been allowed to work for it. It seems that the minimum requirement would have been to become a God-fearer, i.e. to worship God, but not to become a Jew in the full sense of the word. Otherwise the manumitter would have made it a condition of freeing a slave that he become a proselyte.

If we accept the Bellen-Lifshitz emendation, we find that the first condition ( $\theta \omega \pi \epsilon l \alpha=$ To $\sigma \epsilon \beta \epsilon l \nu \theta \epsilon \delta \nu)$ is absent. If we reject this emendation, then the first condition, which the manumitter forgot to mention, is added at the end of the inscription. The fact that the word $\theta \epsilon 0 \sigma \epsilon \beta$ rs has never been found in Bosporan inscriptions also speaks against the possibility of this emendation. In three Bosporan manumissions

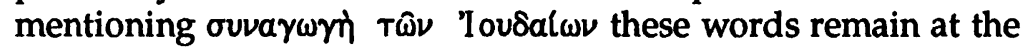
end of the inscriptions, ${ }^{12}$ while the good condition of the inscriptions allows us to conclude that no additions were made

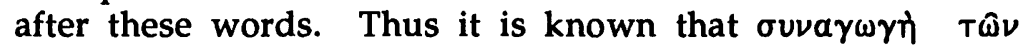

\footnotetext{
${ }^{8}$ B. Nadel, Vestnik dreonei istorii 1 (1958) 145, CIRB 71. See the literature devoted to deviations from Greek grammar in the Bosporan inscriptions in: B. Nadel 'Actes d'affranchissement bosphoriens', Symposion 1971 (1975) 278, n. 33. ${ }^{9} \mathrm{CIRB} 71,73$ (Panticapaeum), 985 (Phanagoria).

${ }^{10} \mathrm{CIG}$ II, 2114bb, J. Derenbourg, 'Les inscriptions grecques juives au Nord de la Mer Noir', JA VI ser. xi (1868) 537.

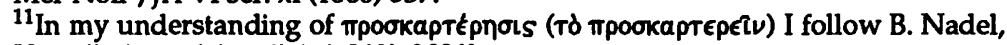
Vestnik dreonei istorii 1 (1948) $203 \mathrm{ff}$.

${ }^{12}$ CIRB 70, 72, 73.
} 


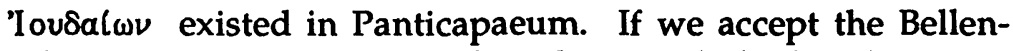
Lifshitz emendation, we are forced to conclude that there was another Jewish community in Panticapaeum at this time, which left no trace other than this inscription. ${ }^{13}$ Of course, this possibility cannot be excluded, but it seems unlikely. Thus, in my opinion, this emendation must be rejected.

B. Nadel, in a critical discussion of the emendation, noted that we are dealing here with a general question 'sur la nécessité ou non des amendations philologiques dans les cas où une interprétation suffisante est possible sans appliquer la chirurgie philologique'. ${ }^{14}$ Using 'philological surgery' in the case of a literary text, we risk editing an ancient author and even improving on him-this can be very tempting. In the case of an inscription, we sometimes risk creating a new fact, a new past reality.

To sum up, it seems to me quite imprudent to use the Panticapaeum inscription as a parallel for the inscription from Aphrodisias. The remark of J. Reynolds and R. Tannenbaum that $\theta \epsilon 0 \sigma \epsilon \beta \epsilon i \hat{s}$ in Panticapaeum were considered 'part of the synagogue community by that community' seems to be a little hasty..$^{15}$

The inscription from Aphrodisias for the first time established as a fact what previously had been discussed as a possibility, i.e. that the word $\theta \epsilon \sigma \sigma \epsilon \beta$ r s could designate a gentile sympathizer with Judaism. All other inscriptions containing this word could equally be interpreted as probably referring to 'the pious', whether Jew or God-fearer. ${ }^{16}$ In scholarly literature the balance was tipped rather more to the Jewish side, not entirely without the authority of L. Robert's opinion. ${ }^{17}$ The inscription from Aphrodisias redressed the balance or even tipped it in the other direction. Bearing this

\footnotetext{
${ }^{13} \mathrm{~B}$. Nadel, op. cit. 278also paid attention to the fact that the omission of an article before the word $\theta \in 0<\nu>\sigma \in \beta a v$ makes it difficult to decide whether the

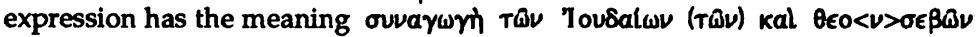

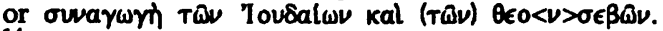

14B. Nadel, loc. cit. 278.

15J. Reynolds and R. Tannenbaum, op. cit. 54.

${ }^{16}$ The complete list is given by J. Reyndolds, R. Tannembaum, op. cit. $53 \mathrm{ff}$.

${ }^{17}$ L. Robert, Nouvelle inscriptions de Sardes (1964) 39-45.
} 
inscription in mind it is worth paying more attention to those features that speak in favour of a non-Jewish origin.

Can this inscription play any rôle in the discussion about God-fearers in Acts? With the work of T.A. Kraabel the discussion entered a new phase, when the very idea of the existence of God-fearers was questioned ${ }^{18}$ and Luke acquired a reputation as the inventor of purely theological schemes. The inscription from Aphrodisias gives the strongest possible rebuttal of Kraabel's doubts, so 'it is clearly premature to proclaim the "disappearance" of the God-fearers'. ${ }^{19}$

But even if at Aphrodisias (and probably elsewhere too) the word $\theta \epsilon 0 \sigma \epsilon \beta$ ins acquired a special meaning, could it be

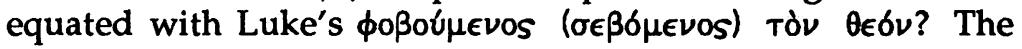
discrepancy between the inscriptional usage and that of Luke, along with diversity in the latter's own usage has given rise to serious doubts. It seems to me that some of those who contributed to this discussion used the word 'term' in a modern scientific sense. They assumed that terms should ideally be words that have a fixed meaning, one and the same whenever they are met. Kirsopp Lake considered that the strongest

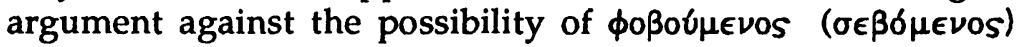
Tò $\theta \epsilon \delta \nu$ being technical terms was that they are perfectly well-known Old Testament phrases'.20 But it is also wellknown that some words have a technical meaning when they are used in a particular context and outside this context have a more general meaning. For instance, the word 'saint' has a technical meaning - a person canonized by the church, but it can also be used to describe a person who is exceptionally meek, charitable, patient, etc. The word mpooriduros at first meant 'a resident alien' and then acquired the meaning 'proselyte' - a convert to Judaism. In LXX, for instance, it is used in both senses. ${ }^{21}$ So it is not impossible for one and the same expression to be used at the same time and even sometimes by the same author in two different ways. The problem is how to distinguish between these usages.

\footnotetext{
${ }^{18}$ The list is given in my article in the previous issue of this journal, 158, n. 27.

${ }^{19}$ Schürer-Vermes-Millar III, I (1986) 168.

${ }^{20} \mathrm{~K}$. Lake, 'Proselytes and God-fearers', in K. Lake and F. Foakes Jackson (eds.), The Beginnings of Christianity, V. I (1933) $87 \mathrm{f}$.

${ }^{21}$ TDNT s. v. Tpootiuutos.
} 
The most serious treatment in recent years of the terms in question in Acts was made by M. Wilcox. ${ }^{22}$ In his conclusions he supported the opinion of Kirsopp Lake that, in Acts of $\phi o \beta o u ́ \mu \epsilon \nu$ o Tò $\theta \epsilon \delta \nu$ referred to the pious in the Jewish community, without any distinction between Jews, proselytes or pagan adherents. In his article he analysed in detail all the passages from Acts, trying to show that in each particular passage it is impossible to say definitely whether the expression had any technical meaning. The traditional understanding, in his opinion, was based on circular arguments. But it seems that in his analysis Wilcox underestimated some grammatical and contextual aspects. I will try to demonstrate this with two examples.

In the Pisidian Antioch Paul addressed two groups-

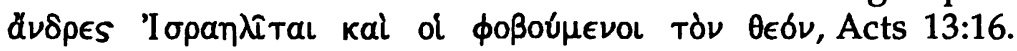
Lake wrote that this passage 'gives almost as good a sense and is quite as accurately rendered if Israelites and God-fearers be regarded as two adjectives applied to the same persons' ${ }^{23}$ Wilcox agreed with this argument and added that the question of whether Luke meant two different groups could not be answered 'on the basis of this verse alone'.24 But the article before $\phi \circ \beta u^{\prime} \mu \epsilon \nu 0 \mathrm{~L}$ speaks very strongly against this possibility. ${ }^{25}$ If we assume that $\phi \circ \beta$ oú $\mu \epsilon \nu$ ol has no technical meaning here and if we still have in mind the presence of an article, then it means that Paul addressed the Jews whom he

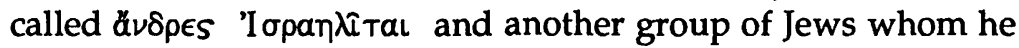
called $\phi \circ \beta o u \mu \epsilon \nu \circ \mathrm{l}$ Tò $\theta \epsilon 6 \nu$. For Judaism $\phi 6 \beta 0 s \quad \theta \epsilon 0 \hat{v}$ is conditio sine qua non. ${ }^{26}$ It acquired the meaning of Latin pietas, religio. ${ }^{27}$

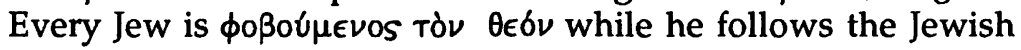
law and stops being so if he breaks with it. So if Paul

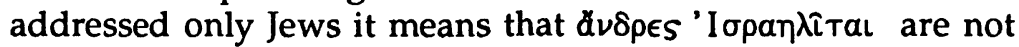
$\phi \circ \beta o u ́ \mu \epsilon \nu$ o todv $\theta \epsilon \delta v$ i.e. not Jews at all. Of course, such a

\footnotetext{
${ }^{22}$ M. Wilcox "The "God-fearers" in Acts-a Reconsideration', JSNT 13 (1981) 102-122.

${ }^{23} \mathrm{~K}$. Lake, op. cit. 86.

${ }^{24} \mathrm{M}$. Wilcox, op. cit. 107.

25J. Reynolds and R.Tannenbaum, op. cit. 51 New Docs (1978) 54.

${ }^{26}$ L.H. Feldman "Jewish "Sympathizers" in Classical Literature and Inscriptions' TAPA 81 (1950) 203.

${ }^{27}$ K. Romaniuk 'Die "Gottesfürchtigen" im Neuen Testament: Beitrag zur neutestamentlichen Theologie der Gottesfurcht', Aegyptus 44:1-2 (1964) 71.
} 
critical attitude towards one's audience is quite possible but it seems that sarcasm is inappropriate for someone who is seeking to convert people.

Acts $18: 7$ is very important for this problem. Wilcox admits that 'this at first sight seems to be one of the strongest and clearest cases for possible technical use of $\sigma \in \beta \delta \mu \epsilon \nu 0 \mathrm{~T}$. Tòv $\theta \varepsilon \delta v^{\prime}{ }^{28}$ But he considers that the name Iustus on its own cannot prove that its bearer was not a Jew. That is why, he adds, that the case rests on the term $\sigma \epsilon \beta \delta \mu \epsilon \nu$ os only and we thus argue neatly in a circle'. As far as the name is concerned he is absolutely right. Jews used to have Roman and Greek names and it is impossible to judge the ethnicity of a particular person from the name alone. But the fact that Iustus was a pagan adherent of Judaism is stressed by the words $\epsilon l s$ Td $E \theta u \eta$

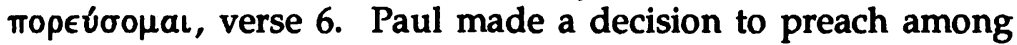
Gentiles and entered the house of $\sigma \in \beta b \mu \epsilon \nu 0 S$ Tov $\theta \in b \nu$. If these two phrases have no logical connection we must either postulate a lacuna in the text or assume that the narrative logic has broken down.

It seems that to assume the technical character of the expression in question is the most economical interpretation from the point of view of both grammatical and narrative logic.

${ }^{28} \mathrm{M}$. Wilcox, op. cit. 113. 